\title{
Optimization of Process parameters for a modified chisel edge HSS drill
}

\author{
P. V. Gopal Krishna ${ }^{1}$ K. Kishore ${ }^{2}$, T. Srihari ${ }^{3}$ \\ ${ }^{1}$ Associate Professor, \\ ${ }^{2}$ Professor, Department of Mechanical Engineering, Vasavi College of Engineering, Ibrahimbagh, \\ Hyderabad, India \\ ${ }^{3}$ Professor, Department of Mechanical Engineering, Shadan College of Engineering and Technology, \\ Peerancheru, Hyderabad, India
}

\begin{abstract}
Drilling is one of the fundamental operations in metal cutting industry. Torque and thrust force has a major influence on the tool life and machining economics. The present study mainly focus on the optimization of process parameters to reduce torque and thrust force on HSS drill and to improve the tool life. Investigations are carried on different work materials such as AA 6041, AISI 1040 and EN8. These investigations are aimed at benefiting small industries that use aforementioned tool work combinations. Regression models are constructed for torque, thrust force.
\end{abstract}

Key words: drilling, torque, thrust, chisel edge, optimization, regression analysis.

\section{Introduction}

Drilling is a hole making operation by rotating a wedge shaped tool called drill. In metal cutting industry, major material removal process is the production of holes in components. One estimate is that $75 \%$ of all metal-cutting material removed comes from drilling operations. Very frequently drilling is a preliminary operation to reaming, boring or grinding where final finishing and sizing takes place. A common twist drill has two cutting edges joined by a chisel edge of $55^{\circ}$ to the plane perpendicular to the cutting plane. The chisel edge decides the web thickness and first interacts with the work as the drill descends into the work, material under the chisel edge is compressed and extruded, the rotating edges will extend the cutting process. The essential short coming of the twist drill is the variations of the rake angle along the length of the cutting edge and the chip formation will be complicated due to negative rake cutting at the chisel edge. A modification is suggested in this work to clear the chip removed near the chisel edge and the findings are reported in this work. Hence drilling has fascinated many investigators.

In addition to the common two flute twist drill there are several other types in use such as flat drills, drills with three or four flutes, core, shell, spade drills. The chips must exit through the flutes to the outside of the tool. The cutting front is embedded within the work piece hence this is restricted machining further the process, makes cooling difficult. The characteristics of drilling that set it apart from other powered metal cutting operations are: 1. The chips must exit out of the hole created by the cutting, 2. Chip exit can cause problems when chips are large and/or continuous, 3 . The drill can wander upon entrance for deep holes, 4 . For deep holes in large work pieces, coolant may need to be delivered through the drill shaft to the cutting front powered metal cutting processes. Drilling on a drill press is the most likely to be performed by someone who is not a machinist.

A.Bhattacharyya,[1] et al have carried out investigation extensively on chisel edge modification of small drills both HSS and carbide type for machining work materials cast iron and mild steel by adopting some special grinding techniques. One such modification is spiro-point drill which could reduce thrust considerably. They optimised the geometry of zhirov-point small HSS and carbide drills. Q.Zhang and J.Wang[2] have studied the critical geometries that uniquely define the drill point design. The study shows that the modified drill design yields positive normal rake angle on the entire lips and point relieving in the chisel edge region. A.Bhattacharyya, [3] et al devised a special technique of grinding which would modify the chisel edge into a pair of cutting edges by developing two small slots at the chisel edge reducing the backing material at the chisel point and converting it into two auxiliary cutting edges of positive rake angles. A.K.Chattopadhyay, and A.B.Chattopadhyay[4] studied the constructional characteristics of some modern ceramic tools and their wear behaviour and overall performances in machining mild steel at both low and high speeds. Audy,[5] presents the results of a systematic computer assisted study focused on determining and describing mathematical model of relationship between the drill point geometry and performance. When drilling a steel work-piece material with general purpose twist drills. Paul[6] investigated the optimization of twist drill point geometries in order to minimize thrust and torque in drilling. Armarego, E. J. A. and Cheng C.Y [7] reported cutting analysis, based on oblique cutting models, and extended the models to the drill lips of flat rake face (modified) drills. The analysis predicts reasonable deformation and force distributions along the drill lips. Armarego, E. J. A. and Cheng, 
C.Y[8] also predicted the effect of geometrical similarity on the deformation and forces of different sized conventional and modified drills through experimentation. The present work focuses on the modification of a chisel edge for $10 \mathrm{~mm}$ and $15 \mathrm{~mm}$ diameter HSS drills. The modifications of chisel edge parameters are found after extensive study of the literature. The aim of present work is to reduce the torque and thrust to increase the life of the drill. We have considered three work materials viz., AA 6041, AISI 1040 and EN 08 and observed reduction of torque and thrust forces from $15 \%$ to $50 \%$ respectively.

\section{Experimentation}

The experiments are carried on a Batliboi make pillar drilling machine and drill dynamometer of Instroll device make was used to measure thrust force and torque. The experimental set up is shown in the figure 1. In the present investigation three materials which are widely used in industry are considered v.i.z AA 6041 AISI 1040, and EN 08. The processing parameters are selected by referring machining hand book and they are shown in table1. Two drills $10 \mathrm{~mm}$ and $15 \mathrm{~mm}$ of Addison make HSS drill of T type was grounded to the standard angels, point angel of $118^{\circ}$, lip clearance angel of $15^{\circ}$, chisel edge angel to $55^{\circ}$ and helix angel $35^{\circ}$. Experiments were conducted on the materials, torque and thrust force was recorded. The chisel edge was further modified by using tool and cutter grinding machine on either side at an angel of $45^{\circ}$. ( to recommended angels by Wang [5]) The experiments are continued by using modified chisel edge drill, torque and thrust force was recorded. The details of torque and thrust force for standard drill and modified chisel edge drill are given in tables 2 to 4 . The drills before and after suggested modification are shown in figure 2 and figure 3 .

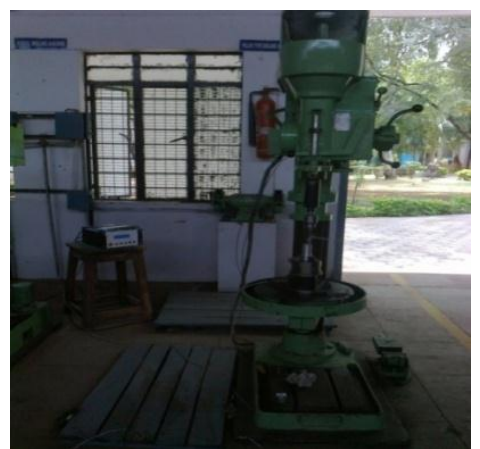

Figure.1 Experimental setup
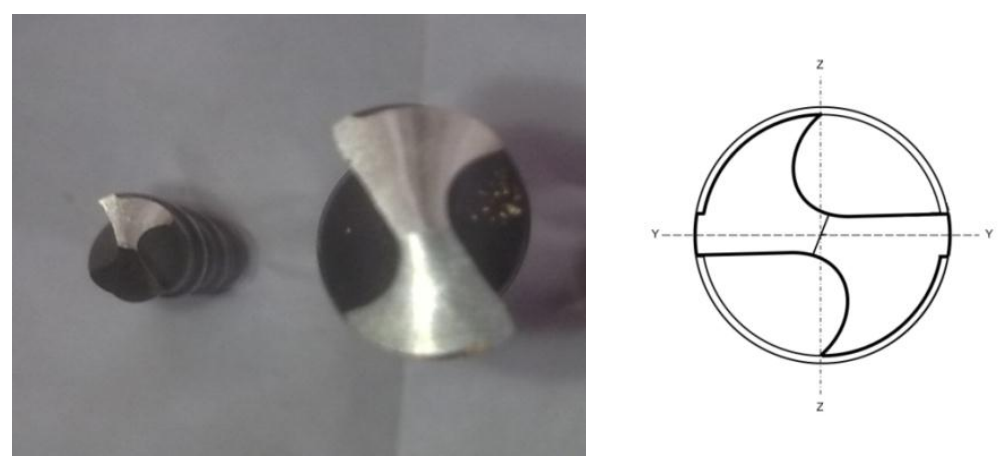

Figure.2. Drills before modification
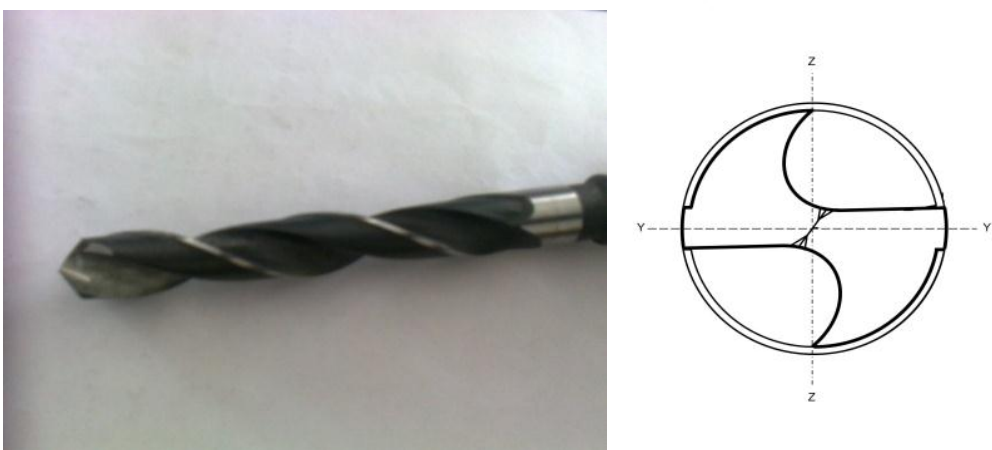

Figure3. Drill after modification 
Optimization of Process parameters for a modified chisel edge HSS drill

\begin{tabular}{|c|c|c|}
\hline Parameters & Level 1 & Level 2 \\
\hline Speed (rpm) & 680 & 360 \\
\hline Feed $(\mathrm{mm} / \mathrm{rev})$ & 0.2 & 0.01 \\
\hline Depth of cut $(\mathrm{mm})$ & 7.5 & 5 \\
\hline
\end{tabular}

Table.1 Selection of process parameters

An $\mathrm{L}_{8}$ orthogonal array was selected as the variables considered are cutting speed, feed and depth of cut. Two level experimentation is preferred for its simplicity a total of $2^{3}=8$ set of experiments need to be conducted. Each experiment is repeated to avoid bias and error. The response parameters of torque and thrust were measured for each condition.

\begin{tabular}{|c|c|c|c|c|c|c|c|}
\hline \multirow[b]{2}{*}{$\begin{array}{c}\text { Trial } \\
\text { no. }\end{array}$} & \multicolumn{3}{|c|}{ Factors } & \multicolumn{2}{|c|}{ standard } & \multicolumn{2}{|c|}{ modified } \\
\hline & $\begin{array}{c}\text { Speed } \\
\text { rpm }\end{array}$ & $\begin{array}{c}\text { Feed } \\
\mathrm{mm}\end{array}$ & $\begin{array}{c}\text { Depth of } \\
\text { cut } \\
\text { Mm }\end{array}$ & $\begin{array}{c}\text { Torque } \\
\text { N-m }\end{array}$ & $\begin{array}{c}\text { Thrust } \\
\mathrm{N}\end{array}$ & $\begin{array}{c}\text { Torque } \\
\text { N-m }\end{array}$ & $\begin{array}{c}\text { Thrust } \\
\mathrm{N}\end{array}$ \\
\hline 2 & 1 & 1 & 2 & 3.05 & 835 & 3.15 & 560 \\
\hline 3 & 1 & 2 & 1 & 3.75 & 1250 & 2.8 & 385 \\
\hline 4 & 1 & 2 & 2 & 1.7 & 555 & 1.7 & 325 \\
\hline 6 & 2 & 1 & 2 & 2.55 & 880 & 2.55 & 525 \\
\hline 7 & 2 & 2 & 1 & 4.4 & 1420 & 4.4 & 585 \\
\hline 8 & 2 & 2 & 2 & 1.25 & 595 & 1.25 & 305 \\
\hline
\end{tabular}

Table2. Experimental matrix for AA 6041using standard and modified drill

\begin{tabular}{|c|c|c|c|c|c|c|c|}
\hline \multirow[b]{2}{*}{$\begin{array}{c}\text { Trial } \\
\text { no. }\end{array}$} & \multicolumn{3}{|c|}{ Factors } & \multicolumn{2}{|c|}{ standard } & \multicolumn{2}{|c|}{ modified } \\
\hline & $\begin{array}{c}\text { Speed } \\
\text { rpm }\end{array}$ & $\begin{array}{c}\text { Feed } \\
\mathrm{mm}\end{array}$ & $\begin{array}{l}\text { Depth of } \\
\text { cut Mm }\end{array}$ & $\begin{array}{c}\text { Torque } \\
\mathrm{N}-\mathrm{m}\end{array}$ & $\begin{array}{c}\text { Thrust } \\
\mathrm{N}\end{array}$ & $\begin{array}{c}\text { Torque } \\
\mathrm{N}-\mathrm{m}\end{array}$ & $\begin{array}{c}\text { Thrust } \\
\mathrm{N}\end{array}$ \\
\hline 1 & 1 & 1 & 1 & 14.95 & 3300 & 15.45 & 2050 \\
\hline 2 & 1 & 1 & 2 & 7 & 1785 & 8.05 & 1205 \\
\hline 3 & 1 & 2 & 1 & 8.2 & 2100 & 8.3 & 920 \\
\hline 4 & 1 & 2 & 2 & 3.85 & 940 & 3.65 & 640 \\
\hline 5 & 2 & 1 & 1 & 15.4 & 3450 & 10.2 & 1495 \\
\hline 6 & 2 & 1 & 2 & 6.95 & 1920 & 6.3 & 1090 \\
\hline 7 & 2 & 2 & 1 & 9.75 & 2405 & 7.65 & 980 \\
\hline 8 & 2 & 2 & 2 & 3.8 & 1145 & 3.15 & 555 \\
\hline
\end{tabular}

Table 3. Experimental matrix for AISI1040 using standard and modified drill

\begin{tabular}{|c|c|c|c|c|c|c|c|}
\hline \multirow[b]{2}{*}{$\begin{array}{c}\text { Trial } \\
\text { no. }\end{array}$} & \multicolumn{3}{|c|}{ Factors } & \multicolumn{2}{|c|}{ standard } & \multicolumn{2}{|c|}{ modified } \\
\hline & $\begin{array}{c}\text { Speed } \\
\mathrm{rpm}\end{array}$ & $\begin{array}{c}\begin{array}{c}\text { Feed } \\
\mathrm{mm}\end{array} \\
\end{array}$ & $\begin{array}{c}\text { Depth ofcut } \\
\text { Mm }\end{array}$ & $\begin{array}{c}\text { Torque } \\
\mathrm{N}-\mathrm{m}\end{array}$ & $\begin{array}{c}\text { Thrust } \\
\mathrm{N}\end{array}$ & $\begin{array}{c}\text { Torque } \\
\mathrm{N}-\mathrm{m}\end{array}$ & $\begin{array}{c}\text { Thrust } \\
\mathrm{N}\end{array}$ \\
\hline 1 & 1 & 1 & 1 & 14.05 & 3230 & 13.1 & 2175 \\
\hline 2 & 1 & 1 & 2 & 6.7 & 1700 & 6.6 & 1145 \\
\hline 3 & 1 & 2 & 1 & 8.4 & 1970 & 8.1 & 1270 \\
\hline 4 & 1 & 2 & 2 & 3.6 & 955 & 2.95 & 695 \\
\hline 5 & 2 & 1 & 1 & 18.45 & 3695 & 10.3 & 1315 \\
\hline 6 & 2 & 1 & 2 & 6.85 & 1855 & 6.1 & 910 \\
\hline 7 & 2 & 2 & 1 & 9.9 & 2405 & 7.35 & 950 \\
\hline 8 & 2 & 2 & 2 & 4.25 & 1115 & 3.6 & 580 \\
\hline
\end{tabular}

Table 4. Experimental matrix for EN08 using standard and modified drill

\section{Analysis of variance and Regression analysis}

Regression analysis is a statistical technique for investigating and modeling the relationship between variables. Applications of regression are numerous and occur in almost every field, including engineering, the physical and chemical sciences, economics, management, life and biological sciences and the social sciences. In fact, regression analysis may be the most widely used statistical technique. Regression analysis generates equation to describe the statistical relationship between one or more predictors and the response variable and to predict new observations. Regression generally uses the ordinary least squares method which derives the equation by minimizing the sum of squared residuals. In this work multiple regressions is used because three factors such as cutting speed, feed and depth of cut are considered for the analysis. The co-relations between the factors (cutting speed, feed and depth of cut) and the measured thrust and torque is obtained by multiple linear regression analysis

Analysis of variance method is also used to study the results obtained from experimental work. This ANOVA technique identifies the significant parameters and calculates the percentage effect of each parameter on thrust and torque on the drill. The use of ANOVA technique approach makes it easy to analyses the results 
and hence makes it fast to reach on the conclusion. The construction of Analysis Of Variance was shown in table 8 to 19 .

\begin{tabular}{|c|l|l|l|l|l|}
\hline Trial No. & \multicolumn{1}{|c|}{ Constantans } & \multicolumn{1}{|c|}{ SS } & \multicolumn{1}{|c|}{ DOF } & \multicolumn{1}{|c|}{$\begin{array}{c}\text { MOS/SSE }= \\
\text { F-Ratio }\end{array}$} \\
\hline 1 & $\mathrm{~b}_{0}=4.65$ & 345.96 & 1 & 345.96 & 3.77773228 \\
\hline 2 & $\mathrm{~b}_{1}=0.375$ & 2.25 & 1 & 2.25 & 0.024569018 \\
\hline 3 & $\mathrm{~b}_{2}=0.4125$ & 2.7225 & 1 & 2.7225 & 0.029728512 \\
\hline 4 & $\mathrm{~b}_{3}=1.075$ & 18.49 & 1 & 18.49 & 0.201902734 \\
\hline 5 & $\mathrm{~b}_{4}=-0.6125$ & 6.0025 & 1 & 6.0025 & 0.065544681 \\
\hline 6 & $\mathrm{~b}_{5}=1.0375$ & 17.2225 & 1 & 17.2225 & 0.188062187 \\
\hline 7 & $\mathrm{~b}_{6}=-0.925$ & 13.69 & 1 & 13.69 & 0.149488828 \\
\hline 8 & $\mathrm{~b}_{7}=0.5875$ & 5.5225 & 1 & 5.5225 & 0.060303291 \\
\hline
\end{tabular}

Table.5. ANOVA for Torque -AA6041- standard drill

\begin{tabular}{|c|l|l|l|l|l|}
\hline Trial No. & \multicolumn{1}{|c|}{ Constantans } & \multicolumn{1}{|c|}{ SS } & \multicolumn{1}{|c|}{ DOF } & \multicolumn{1}{|c|}{$\begin{array}{c}\text { MOS } / \text { SSE }= \\
\text { F-Ratio }\end{array}$} \\
\hline 1 & $\mathrm{~b}_{0}=1197.50$ & 22944100.00 & 1 & 22944100.00 & 8.114731849 \\
\hline 2 & $\mathrm{~b}_{1}=62.50$ & 62500.00 & 1 & 62500.00 & 0.022104626 \\
\hline 3 & $\mathrm{~b}_{2}=242.50$ & 940900.00 & 1 & 940900.00 & 0.332771876 \\
\hline 4 & $\mathrm{~b}_{3}=481.25$ & 3705625.00 & 1 & 3705625.00 & 1.310583253 \\
\hline 5 & $\mathrm{~b}_{4}=-10.00$ & 1600.00 & 1 & 1600.00 & 0.000565878 \\
\hline 6 & $\mathrm{~b}_{5}=481.25$ & 3705625.00 & 1 & 3705625.00 & 1.310583253 \\
\hline 7 & $\mathrm{~b}_{6}=-41.25$ & 27225.00 & 1 & 27225.00 & 0.009628775 \\
\hline 8 & $\mathrm{~b}_{7}=-361.75$ & 2117025.00 & 1 & 2117025.00 & 0.748736721 \\
\hline
\end{tabular}

Table.6. ANOVA for Thrust - AA6041- standard drill

\begin{tabular}{|c|l|l|l|l|l|}
\hline Trial No. & \multicolumn{1}{|c|}{ Constantans } & \multicolumn{1}{|c|}{ SS } & DOF & \multicolumn{1}{c|}{$\begin{array}{c}\text { MOS } / \text { SSE }= \\
\text { F-Ratio }\end{array}$} \\
\hline 1 & $\mathrm{~b}_{0}=3.16875$ & 160.65563 & 1 & 160.65563 & 10.69366615 \\
\hline 2 & $\mathrm{~b}_{1}=-0.0813$ & 0.105625 & 1 & 0.105625 & 0.007030681 \\
\hline 3 & $\mathrm{~b}_{2}=0.63125$ & 6.375625 & 1 & 6.375625 & 0.424378575 \\
\hline 4 & $\mathrm{~b}_{3}=1.00625$ & 16.200625 & 1 & 16.200625 & 1.078356734 \\
\hline 5 & $\mathrm{~b}_{4}=0.20625$ & 0.680625 & 1 & 0.680625 & 0.045304212 \\
\hline 6 & $\mathrm{~b}_{5}=-0.0563$ & 0.0505625 & 1 & 0.0505625 & 0.003369735 \\
\hline 7 & $\mathrm{~b}_{6}=-0.3438$ & 1.890625 & 1 & 1.890625 & 0.125845034 \\
\hline 8 & $\mathrm{~b}_{7}=-0.1688$ & 0.455625 & 1 & 0.455625 & 0.030327613 \\
\hline
\end{tabular}

Table.7. ANOVA for Torque - AA6041 - Modified drill

\begin{tabular}{|c|l|l|l|l|l|}
\hline Trial No. & \multicolumn{1}{|c|}{ Constantans } & \multicolumn{1}{|c|}{ SS } & \multicolumn{1}{|c|}{ DOF } & \multicolumn{1}{|c|}{$\begin{array}{c}\text { MOS/SSE }= \\
\text { F-Ratio }\end{array}$} \\
\hline 1 & $\mathrm{~b}_{0}=488.125$ & 3812256.25 & 1 & 3812256.25 & 368.5425777 \\
\hline 2 & $\mathrm{~b}_{1}=-38.125$ & 23256.25 & 1 & 23256.25 & 2.248253465 \\
\hline 3 & $\mathrm{~b}_{2}=88.125$ & 124256.25 & 1 & 124256.25 & 12.01223519 \\
\hline 4 & $\mathrm{~b}_{3}=62.5$ & 62500 & 1 & 62500 & 6.042067898 \\
\hline 5 & $\mathrm{~b}_{4}=8.75$ & 1225 & 1 & 1225 & 0.118424531 \\
\hline 6 & $\mathrm{~b}_{5}=-22.5$ & 8100 & 1 & 8100 & 0.783052 \\
\hline 7 & $\mathrm{~b}_{6}=-45$ & 32400 & 1 & 32400 & 3.132207998 \\
\hline 8 & $\mathrm{~b}_{7}=10$ & 1600 & 1 & 1600 & 0.154676938 \\
\hline
\end{tabular}

Table.8. ANOVA for Thrust - AA6041- Modified drill

\begin{tabular}{|c|c|c|c|}
\hline & & Torque N-m & Thrust N \\
\hline \multirow{2}{*}{ AA 6041} & Standard & $\begin{array}{l}\mathrm{y}=4.65+0.375 \mathrm{x}_{1}+0.4125 \mathrm{x}_{2}+1.075 \mathrm{x}_{3}-0.612 \mathrm{x}_{1} \mathrm{x}_{2}+1.037 \mathrm{x}_{2} \mathrm{x}_{3}- \\
0.925 \mathrm{x}_{3} \mathrm{x}_{1}+0.587 \mathrm{x}_{1} \mathrm{x}_{2} \mathrm{x}_{3}\end{array}$ & $\begin{array}{l}\mathrm{y}=62.50 \mathrm{x}_{1}+242.50 \mathrm{x}_{2}+481.25 \mathrm{x}_{3}-10.00 \\
\mathrm{x}_{1} \mathrm{x}_{2}+481.25 \mathrm{x}_{2} \mathrm{x}_{3}-41.25 \mathrm{x}_{3} \mathrm{x}_{1}-363.75 \mathrm{x}_{1} \mathrm{x}_{2} \mathrm{x}_{3}\end{array}$ \\
\hline & modified & $\begin{array}{l}y=-0.081 x_{1}+0.631 x_{2}+1.006 x_{3}+0.206 x_{1} x_{2}-0.056 x_{2} x_{3}- \\
0.343 x_{3} x_{1}-0.168 x_{1} x_{2} x_{3}\end{array}$ & $\begin{array}{l}\mathrm{y}=-38.125 \mathrm{x}_{1}+88.125 \mathrm{x}_{2}+62.5 \mathrm{x}_{3}+8.75 \mathrm{x}_{1} \mathrm{x}_{2} \\
-22.5 \mathrm{x}_{2} \mathrm{x}_{3}-45 \mathrm{x}_{3} \mathrm{x}_{1}+10 \mathrm{x}_{1} \mathrm{x}_{2} \mathrm{x}_{3}\end{array}$ \\
\hline \multirow[b]{2}{*}{$\begin{array}{l}\text { AISI } \\
1040\end{array}$} & Standard & $\begin{array}{l}\mathrm{y}=-0.237 \mathrm{x}_{1}+2.337 \mathrm{x}_{2}+3.337 \mathrm{x}_{3}+0.137 \mathrm{x}_{1} \mathrm{x}_{2}+0.762 \mathrm{x}_{2} \mathrm{x}_{3^{-}} \\
0.262 \mathrm{x}_{3} \mathrm{x}_{1}+0.1375 \mathrm{x}_{1} \mathrm{x}_{2} \mathrm{x}_{3}\end{array}$ & $\begin{array}{l}y=-36.25 x_{1}+421.25 x_{2}+620 x_{3}-35 x_{1} x_{2}+ \\
141.25 x_{2} x_{3}-76.25 x_{3} x_{1}+72.5 x_{1} x_{2} x_{3}\end{array}$ \\
\hline & modified & $\begin{array}{l}y=1.018 x_{1}+2.156 x_{2}+2.556 x_{3}+0.731 x_{1} x_{2}+ \\
0.268 x_{2} x_{3}+0.456 x_{3} x_{1}+0.418 x_{1} x_{2} x_{3}\end{array}$ & $\begin{array}{l}y=86.875 x_{1}+343.125 x_{2}+244.375 x_{3} \\
+80.625 x_{1} x_{2}+68.125 x_{2} x_{3}+36.875 x_{3} x_{1}+ \\
73.125 x_{1} x_{2} x_{3}\end{array}$ \\
\hline \multirow[t]{2}{*}{ EN8 } & Standard & $\begin{array}{l}\mathrm{y}=8.771-0.584 \mathrm{x}_{1}+2.740 \mathrm{x}_{2}+3.928 \mathrm{x}_{3}+1.528 \mathrm{x}_{1} \mathrm{x}_{2}- \\
1.271 \mathrm{x}_{2} \mathrm{x}_{3}+1.190 \mathrm{x}_{3} \mathrm{x}_{1}+1.909 \mathrm{x}_{1} \mathrm{x}_{2} \mathrm{x}_{3}\end{array}$ & $\begin{array}{l}y=-500893.75 x_{1}+1286906.25 x_{2}+1454 \\
43.75 x_{3}+28406.25 x_{1} x_{2}+610556.25 x_{2} x_{3-}^{-} \\
389706.25 x_{3} x_{1}+212193.75 x_{1} x_{2} x_{3}\end{array}$ \\
\hline & modified & $\begin{array}{l}\mathrm{y}=6.559-0.278 \mathrm{x}_{1}+1.059 \mathrm{x}_{2}+1.746 \mathrm{x}_{3}-0.303 \mathrm{x}_{1} \mathrm{x}_{2}-0.478 \mathrm{x}_{2} \mathrm{x}_{3^{-}} \\
0.240 \mathrm{x}_{3} \mathrm{x}_{1}-0.590 \mathrm{x}_{1} \mathrm{x}_{2} \mathrm{x}_{3}\end{array}$ & $\begin{array}{l}\mathrm{y}=1442.50-121.25 \mathrm{x}_{1}+568.75 \mathrm{x}_{2}+610 \mathrm{x}_{3^{-}} \\
230 \mathrm{x}_{1} \mathrm{x}_{2}+373.75 \mathrm{x}_{2} \mathrm{x}_{3}-208.75 \mathrm{x}_{3} \mathrm{x}_{1}-260 \mathrm{x}_{1} \mathrm{x}_{2} \mathrm{x}_{3}\end{array}$ \\
\hline
\end{tabular}

Table 9. Regression analysis for standard and modified drill.

Wehe $\mathrm{x}_{1}$ - cutting speed, $\mathrm{x}_{2}$-depth of cut, $\mathrm{x}_{3}$-feed rate . 
IV. Results and Discussions
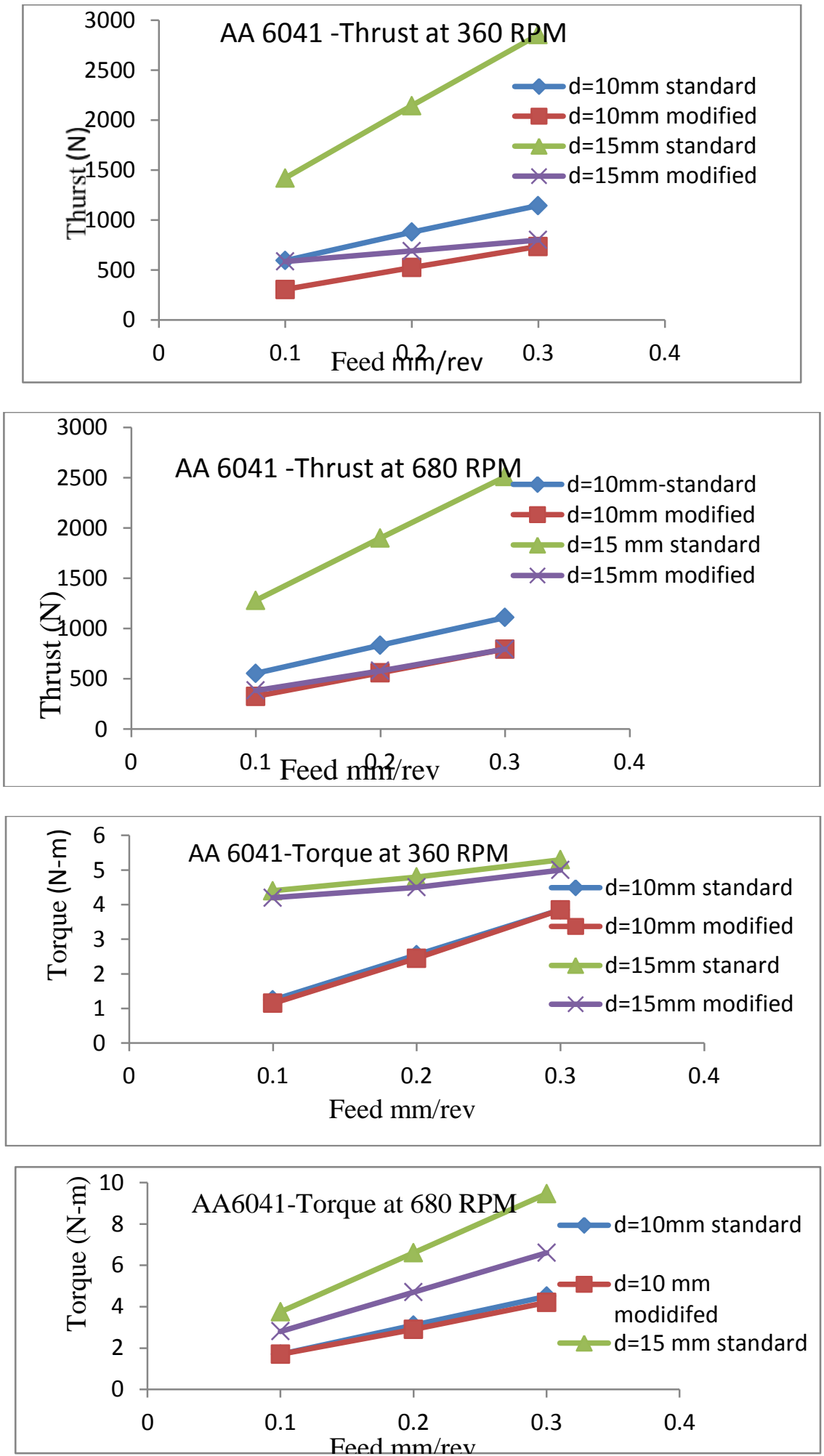

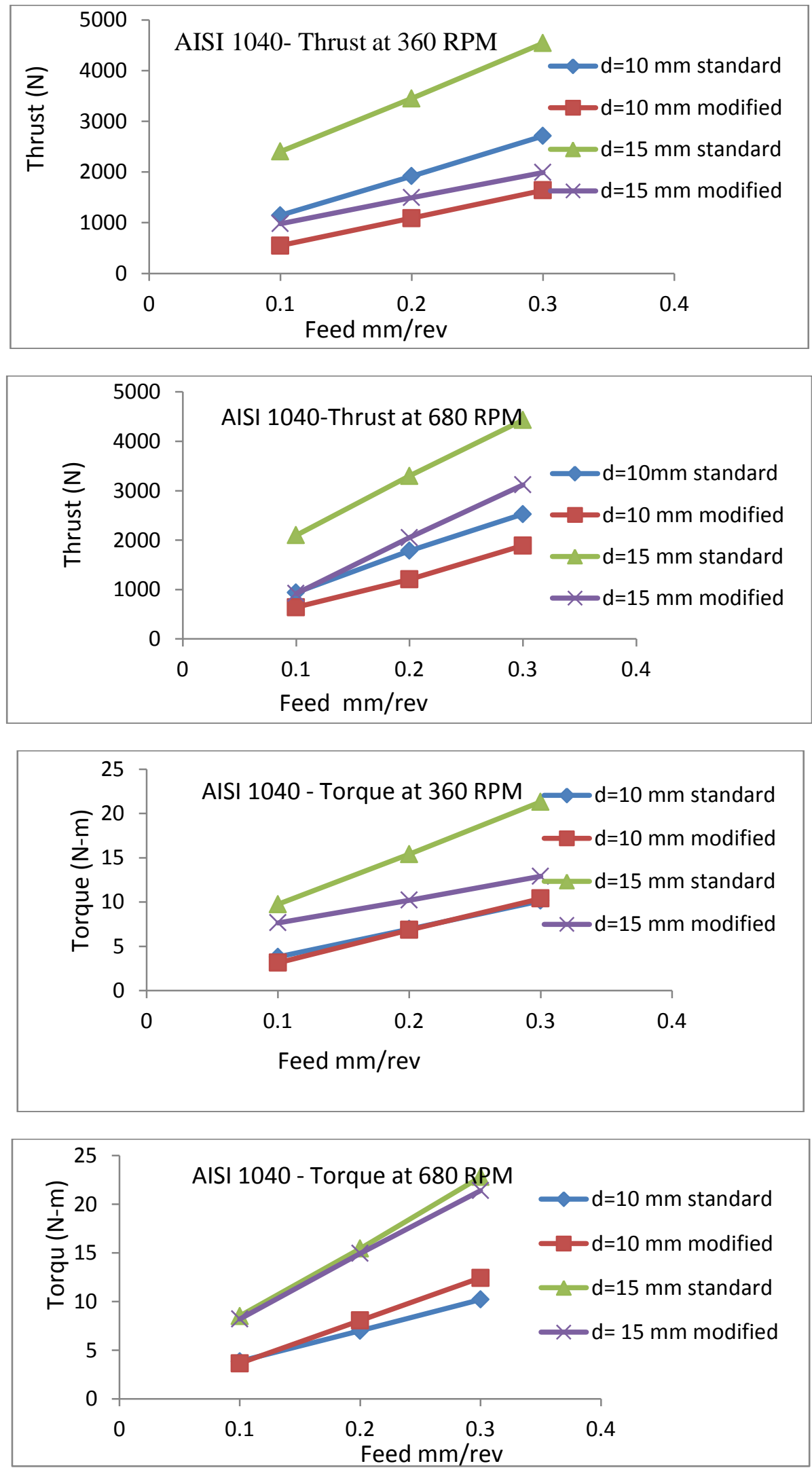

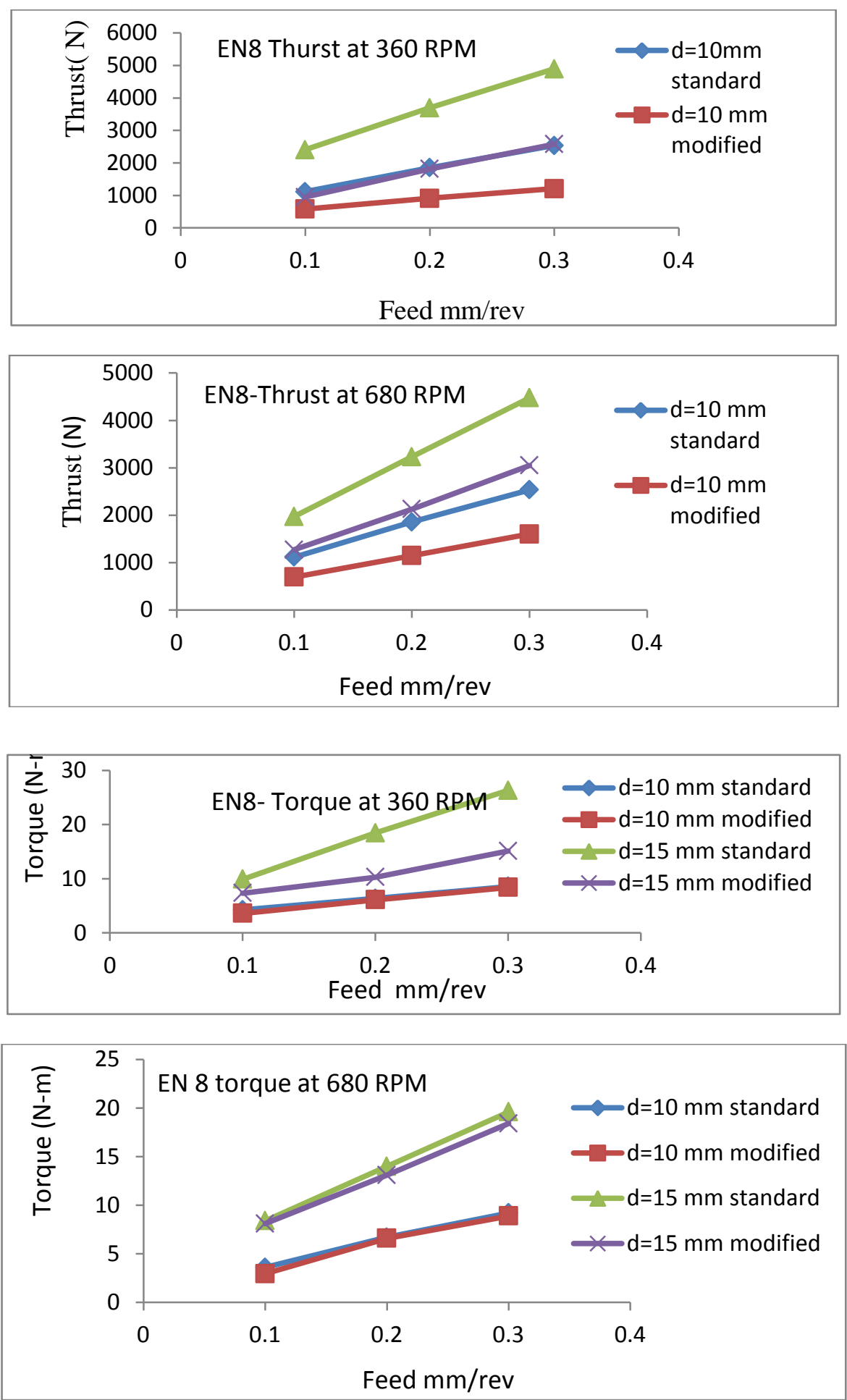

The thrust and torque are observed to increase with feed rate as expected for both standard and modified drills. There is a significant reduction in torque and thrust for modified drills at smaller depth of cut. At low cutting speed the effects of modification was compromised and the same thrust and torque was observed for Aluminum, this may be due to adhesion of the chip at low speed. The thrust and torque were observed to be reduced for $15 \mathrm{~mm}$ drill at cutting speed of $40 \mathrm{~m} / \mathrm{min}$. For EN08 the favorable cutting speed to extract the benefit of modification is suggested as $32 \mathrm{~m} / \mathrm{min}$. 


\section{Conclusions}

The optimization of process parameters for modified chisel edge HSS drill is found satisfactory after observing torque and thrust for three materials AA 6041, AISI 1040, EN08.

1. Thrust has considerably reduced by $50 \%$ for AA6041, $42 \%$ AISI 1040, 35\% for EN08 whereas torque is reduced by $18 \%$ for AA6041, 15\% AISI 1040, $12 \%$ for EN08.

2. Standard drill was used for AA 6041, the depth of cut has major influence followed by feed and speed for torque. The interaction of speed and depth of cut, feed and depth of cut is influencetorque. But for a modified drill the depth of cut has major influence followed by feed rate.

3. The modification was found to be effective for ferrous materials.

4. The modification did not reduce thrust and torque for Aluminium due to chip adhesion at the chisel edge for low cutting speeds.

5. The thrust component for a HSS standard drill used for AA 6041 was mainly contributed by depth of cut and feed rate. The interaction of feed and depth also has some influence. But for modified drill feed rate and depth are contributing equally.

6. Depth of cut and feed has major influence for a standard drill and modified drill on torque. The interaction of feed and depth for standard drill and interaction of cutting speed and feed for a modified drill has some influence on torque.

7. For a modified drill, the thrust was influenced by feed followed by depth of cut for AISI 1040.The interaction of above two parameters have influence. Whereas for standard drill, the depth of cut followed by feed for AISI 1040

8. The torque component for EN 08 for standard was largely contributed by depth of cut and feed rate. The interaction also influences the torque whereas for modified drill, the depth of cut and feed rate only influence the torque.

9. The thrust component for EN 08 for both standard and modified drill was influenced by depth of cut and feed rate. Interaction of feed and depth has some influence for modified and standard drills.

\section{References}

[1] A.Bhattacharyya, A.B. Chattopadhyayand R.Roy, 1981, "Chisel-Edge Modification of Small HSS and Carbide Drills for Improved Machinability", "CIRP Annals-Manufacturing Technology”, Volume 30, Issue 1, Page 21-25.

[2] Q.Zhang and J.Wang, 2010, "Geometry, specification and drilling performance of a plane rake faced drill point design", "Proceedings of the Institution of Mechanical Engineers, Part C: Journal of Mechanical Engineering Science", Volume 224, Issue 2, Page 369-378.

[3] A.Bhattacharyya, A.B.Chatterjee, Inyong Ham, Ajit Bhattacharyya, 1971, "Modification of Drill point for Reducing Thrust", Trans ASME, "Journal of Engineering for Industry", page 1073-1078.

[4] A.K.Chattopadhyay, A.B.Chattopadhyay, 1983, "Wear Characteristics of Ceramic Cutting Tools in Machining Steel", "Wear", Volume 93, Issue 3, Page 347-359.

[5] Audy.J. A., 2008, "Study of computer-assisted analysis of effects of drill geometry and surface coating on forces and power in drilling", .’J. Mater. Process. Tech".,204, Page130-138

[6] Paul, A., Kapoor, S. G., and DeVor, R. E, 2005. "Chisel edge and cutting lip shape optimization for improved twist drill point design”, “Int. J. Mach. Tools Manuf”., 45, Page 421-431.

[7] Armarego, E. J. A. and Cheng, C.Y.,1972, "Drilling with flat rake face and conventional twist drills - part I: theoretical investigation", "Int. J. Mach. Tool Des. Res". Res., 12, Page 7-35.

[8] Armarego, E. J. A. and Cheng, C.Y.,1972, "Drilling with flat rake face and conventional twist drills - part II: experimental investigation", "Int. J. Mach. Tool Des. Res"., 12,Page 37-54.

[9] Udiljak.T, Ciglar.D, Skoric.S, 2007, "Investigation into Bone Drilling and Thermal Bone Necrosis", "Advances in Production Engineering and Management", Volume 2, Issue 3, Page 103-112.

[10] Milton C. Shaw, 1992,"Metal Cutting Principles", CBS Publishers and Distributors, Delhi.

[11] A.Bhattacharyya, 1984,"Metal Cutting Theory and practice", New Central Book Agency (P) Ltd, Kolkata.

[12] Phillip J.Ross, 2005,"Taguchi Techniques for Quality Engineering”, Tata McGraw-Hill.

[13] S.K.Hajra Chowdhury, A.K.Hajra Chowdhury and Nirjhar Roy, 2007, "Workshop Technology", Volume 2, Media Promoters and Publishers Pvt.Ltd., Mumbai. 